\title{
PENGARUH MODEL PROJECT BASED LEARNING TERHADAP KEMAMPUAN BERPIKIR KRITIS IPA SISWA KELAS V SEKOLAH DASAR
}

\author{
${ }^{1}$ Mawardi, ${ }^{2}$ Puput Arum Puspita Sari \\ 1,2Universitas Muhammadiy ah Tangerang \\ e-mail : wardi.elmawardi@gmail.com \\ e-mail: puputarum04@gmail.com
}

\begin{abstract}
Abstrak
Hasil belajar yang kurang maksimal menunjukkan kemampuan berpikir kritis siswa yang kurang maksimal pula Sa lah satu model pembelajaran y ang da pat meningkatkan kemampuan berpikir kritis siswa a dalah problem based learning. Penelitian ini bertujuan untuk menge tahui perbedaan an tara me tode pembelajaran Project-Based Learning terhadap kemampuan berpikir kritis siswa. Penelitian ini dilakukan di SD Negeri Mekarsari 1 Kabupaten Tangerang. Metode yang digunakan dalam penelitia $n$ ini a dalah metode Quasi Eksperimen dengan desain peneltian Nonequivalent Control Grup Design. Sampel penelitian ini adalah 67 siswa yang terdiri dari 36 untuk kelas eksperimen dan 31 un tuk kelas con trol. Instrument penelitian yang digunakan sebagai tes kemampuan berpikir kritis siswa adalah 15 butir soal esay. Teknik analisis data dalam penelitian ini a dalah uji-t untuk menguji hipotesis y ang dia jukan. Da ri hasil perhitungan yang telah dilakukan ternyata diperoleh $t_{\text {hitung }}$ sebesar 6,778 pada taraf signifikan $\alpha=5 \%$ yang kemudian dibandingkan dengan $t_{\text {tabel }}$ sebesar 2,028. Karena $t_{\text {hitung }}>t_{\text {tabel }}(6,778>2,028) \mathrm{m}$ aka $\mathrm{H}_{0}$ ditolak dan $\mathrm{H}_{1}$ diterima. Sehingga dapat disimpulkan bahwa terdapat perbedaan kemampuan berpik ir kritis antara siswa yang diberi model pembelajaran Project-Based Learning dengan sis wa yang diberi model pembelajaran konvensional.
\end{abstract}

Kata Kunci : Kemampuan Berpikir Kritis, Project-Based Learning, Ilmu Pengetahuan Alam

\begin{abstract}
Less optimal learning results show the ability to think critically students are less than optimal One of the learning models that can improve students' critical thinking skills is problem basedlearning. This study attempts to knows the difference between a method oflearning project-based learning on ability to think critically students. The study is done in public primaryschools Mekarsari 1 Tangerang. Methods used in research this is the method quasi his experiments withdesign peneltiannonequivalent control group design. The sample this is 67 students who consisted of 36 for the class experimentation and 31 for the class control.Instrument research used as tests the ability of think critically the students were $15 \mathrm{~g}$ rain $\mathrm{s}$ about esay. Technique data analysis in this research was uji-t to test hypothesis advanced by. Of the calculation on that has been done in fact obtained thitung of 6,778 the first significant $\alpha=5 \%$ is compared with ttabel of 2,028. Because thitung \& $\mathrm{gt}$; ttabel $(6,778$ \& $\mathrm{gt} ; 2,028$ and h0 were rejected and hl accepted. So it can be concluded that there were differences between critical thinking skills students who were given a model oflearning project-based learning with students who were given conventional learning model.
\end{abstract}

Key Words: Critical Thinking Skills, Project-Based Learning, Natural Sciences 


\section{PENDAHULUAN}

United Nations Educational, Scientific and Cultural Organization (UNESCO) menetapkan bahwa salah satu kemampuan yang perlu dibekali pada siswa di abad 21 yaitu keterampilan berpikir kritis (Sani 2014). Berdasarkan penelitian dalam berbagai bidang seperti sosial sains diketahui bahwa peserta didik yang lulus dari berbagai negara tidak memiliki kemampuan untuk bersaing pada skala global karena tidak memiliki kemampuan untuk berpikir secara kritis (Fritjers et al. 2008).

Robbins (2005) mengatakan kemampuan berpikir kritis merupakan kemampuan yang dapat dilatihkan, sehingga kemampuan ini dapat dipelajari. Salah satu cara mengembangkan kemampuan berpikir kritis yaitu melalui pembelajaran Ilmu Pengetahuan Alam.

Permendikbud No. 37 Tahun 2018, tujuan kurikulum IPA mencakup empat kompetensi, yaitu (1) Kompetensi sikap spiritual, dengan menghayati dan mengamalkan ajaran agama yang dianutnya; (2) Sikap sosial, degan menunjukkan perilaku jujur, disiplin, tanggung jawab, santun, peduli, dan percaya diri dalam berinteraksi dengan keluarga, teman, guru, dan tetangganya serta cinta tanah air; (3) pengetahuan; (4) keterampilan.

Pengembangan potensi siswa dimulai sejak jenjang pendidikan dasar, menengah, hingga di perguruan tinggi. Pendidikan dasar merupakan pondasi awal bagi siswa untuk membuka wawasannya dan memegang peranan penting untuk meningkatkan sumber daya manusia di masa yang akan datang. Peran guru ditingkat sekolah dasar juga menjadi kunci untuk pencapaian tujuan pembelajaran dalam proses pembelajaran. Guru sebagai pendidik berperan penting untuk mengatur, mengarahkan, dan menciptakan suasana kegiatan pembelajaran yang mendukung pencapaian tujuan pembelajaran.

Berpikir kritis merupakan kemampuan berpikir yang menggunakan proses analisis dan evaluasi dalam sebuah permasalahan sehingga menghasilkan keputusan yang te pat dalam penyelesaian masalah. Berpikir kritis juga merupakan pengambilan keputusan yang berdasarkan dengan bukti dan alasan yang logis. Kemampuan berpikir kritis dapat dikembangkan sejak sekolah dasar melalui proses pembelajaran pada mata pelajaran IPA.

Pembelajaran Ilmu Pengetahuan Alam (IPA) perlu diberikan kepada semua siswa mulai dari sekolah dasar hingga sekolah menengah. IPA sangat berperan penting baik 
dalam disiplin ilmu maupun dalam kehidupan sehari-hari. Oleh karena itu, konsepkonsep dasar IPA harus diajarkan dan dikuasai sejak dini sehingga dalam kehidupan sehari-hari dapat dilakukan dengan benar. Pembelajaran IPA merupakan cara untuk membangkitkan minat manusia agar dapat mengetahui tentang alam seisinya secara sistematik, dan melatih berpikir kritis, objektif serta memiliki sikap ilmiah.

Kenyataan di sekolah, pendidikan sains belum banyak yang berorientasi ke arah pembiasaan dan peningkatan kemampuan berpikir tingkat tinggi (berpikir kritis), tetapi masih menitikberatkan pada hasil belajar kognitif tingkat rendah. Siswa menyerap informasi secara pasif dan kemudian mengingatnya pada saat mengikuti tes (Bassham et al. 2010). Hal ini juga terjadi pada siswa di Sekolah Dasar Negeri Mekarsari 1 Kabupaten Tangerang yang menunjukkan bahwa kemampuan siswa dalam menyerap materi belum tercapai secara maksimal Adapun faktor-faktor yang mempengaruhi rendahnya nilai pada mata pelajaran IPA antara lain: (1) di kelas proses pembelajaran guru masih menggunakan proses pembelajaran yang konvensional, (2) guru kurang memanfaatkan media pembelajaran, lingkungan kelas yang kurang kondusif, (3) siswa kurang motivasi dalam belajar dan minat siswa dalam mengikuti proses pembelajaran yang masih kurang, dan (4) siswa bersikap pasif di kelas sehingga pada saat guru melakukan tanya jawab hanya sedikit siswa yang menjawab pertanyaan dari gur. Keaktifan siswa yang kurang contohnya seperti minimnya keberanian untuk mengungkapkan pendapat atau mengungkapkan gagasannya, kurang bisa kerjasama dalam kegiatan kelompok dan motivasi belajar mereka juga masih rendah yang membuat keterampilan berpikir kritis mereka kurang maksimal atau rata-rata nilai mereka masih jauh dari nilai KKM yang ditentukan.

Hasil survey TIMSS Tahun 2011 dan PISA Tahun 2012 menunjukkan peringkat literasi sains Indonesia adalah 64 dari 65 negara peserta (NCES, 2013). Hal tersebut menunjukkan bahwa kualitas pendidikan di Indonesia terutama dalam bidang sains jauh tertinggal dibandingkan negara lain. Hasil studi terbatas dengan memberikan ulangan harian materi sistem ekskresi pada tahun 2014/2015 diketahui 45\% siswa belum mencapai KKM. Analisis daya serap Ujian Nasional Tahun 2015 menunjukkan bahwa penguasaan konsep sistem ekskresi pada manusia dan gangguannya di SMAN 1 Singorojo adalah 48,48\% (BSNP 2015). Hasil belajar yang kurang maksimal menunjukkan kemampuan berpikir kritis siswa yang kurang maksimal pula. Hal ini 


\section{Indonesian Journal of Elementary Education \\ Vol.1 No.1 Desember 2019 \\ E-ISSN 2722-6689 \\ http://jurnal.umt.ac.id/index.php/lJOEE}

sejalan dengan yang ditulis Hassoubah (2002) bahwa salah satu kemampuan yang mendukung kemampuan kognitif adalah kemampuan berpikir kritis, kemampuan berpikir kritis yang baik akan meningkatkan kemampuan memecahkan masalah baik akademik maupun non akademik. Salah satu model pembelajaran yang dapat meningkatkan kemampuan berpikir kritis siswa adalah pembelajaran berbasis masalah (problem based learning). Tujuan penelitian ini untuk mengetahui pengaruh model Problem Based Learning (PBL) terhadap kemampuan berpikir kritis siswa pada mata pelajaran Ilmu Pengetahuan Alam.

Banyak model yang dapat digunakan oleh guru dalam penyampaian materi pembelajaran yang dapat membuat siswa lebih aktif dan dapat berpikir kritis dalam mata pelajaran IPA, salah satunya model pembelajaran Project-Based Learning. Dengan menggunakan model pembelajaran Project-Based Learning mampu membangun kemampuan siswa dengan melibatkannya dalam kerja proyek yang menghasilkan suatu hasil karya nyata/ produk untuk mempermudah siswa dalam memahami materi pembelajaran, sehingga siswa lebih tertarik mengikut proses pembelajaran. Diharapkan model pembelajaran Project-Based Learning dapat membantu mencapai tujuan pembelajaran yang ada di sekolah.

Pembelajaran dengan model PBL didasarkan pada prinsip bahwa masalah dapat digunakan sebagai titik awal untuk mendapatkan ilmu baru. Cuhadaroglu (2003) dalam Akinoglu (2007) mengatakan model PBL dapat mengubah siswa dari menerima informasi pasif menjadi aktif (student centered). Beberapa hasil penelitian yang menerapkan PBL dalam pembelajaran memberikan hasil yang positif. Sari (2012) menyimpulkan bahwa penerapan PBL di SMP Negeri 5 Sleman dapat meningkatkan kemampuan berpikir kritis siswa pada pembelajaran IPA. Lien (2009) menyatakan bahwa pembelajaran PBL dapat meningkatkan kemampuan berpikir kritis dan keterampilan belajar mandiri siswa. Hadi et al. (2010) menyatakan bahwa PBL mempunyai pengaruh positif terhadap kemampuan berpikir kritis dan pemahaman konsep biologi siswa SMA Negeri di kota Malang. Adapun tujuan dari penelitian ini adalah untuk menguatkan penelitian-penelitian sebelumya terakait pengaruh model Project-Based Learning terhadap kemampuan berpikir kritis siswa pada mata pelajaran Ilmu Pengetahuan Alam pada siswa kelas V di SDN Mekarsari 1 Kabupaten Tangerang. 


\section{METODE PENELITIAN}

Penelitian ini menggunakan metode eksperimen berupa pemberian treatment pembelajaran Ilmu Pengetahuan Alam dengan model Project Based Learning kemudian dianalisis bagaimana pengaruhnya terhadap kemampuan berpikir kritis siswa. Dalam penelitian ini penulis akan menggunakan dua kelas yaitu satu kelas sebagai kelas eksperimen yang menerapkan pembelajaran dengan model Project Based Learning, dan satu kelas sebagai kelas control yang menerapakan model konvensional. Populasi dalam penelitian ini adalah siswa kelas V SDN Mekarsari 1 dan sampel penelitian ini adalah kelas VA yang berjumlah 36 siswa dan kelas VB yang berjumlah 31 siswa. Berpikir

Untuk memperoleh data dalam penelitian ini, penulis menggunakan teknik pengumpulan data antara lain berupa teknik pokok yang digunakan untuk mengetahui kemampuan kemampuan berpikir kritis siswa adalah teknik tes. Tes ini dilakukan untuk mendapatkan data yang berbentuk angka-angka atau nilai tentang hasil belajar Ilmu Pengetahuan Alam kemampuan berpikir kritis IPA siswa kelas V Sekolah dasar yang bertujuan untuk menguji kebenaran hipotesis dari sejumlah soal yang harus dijawab siswa guna mengetahui hasilnya yang terlebih dahulu dilakukan uji validitas dan reliabilitas. Teknik pengujian hipotesis yang digunakan pada penelitian ini adalah $u j i-t$ dengan uji prasyarat analisis (uji normalitas dan uji homogenitas). Uji homogenitas.

\section{HASIL DAN PEMBAHASAN}

Hasil penelitian yang dilakukan pada siswa kelas V di SDN Mekarsari 1 Kabupaten Tangerang terhadap pembelajaran Ilmu pengetahuan Alam. Data kemampuan berpikir kritis siswa yang diperoleh dari nilai posttest kelas eksperimen dan kelas kontrol disajikan pada Tabel 1. Berdasarkan hasil analisis nilai posttest dapat dilihat bahwa rata-rata nilai kemampuan berpikir kritis kelas eksperimen yang menggunakan pembelajaran IPA model PBL lebih tinggi dibandingkan siswa kelas kontrol yang menggunakan metode ceramah dan diskusi. Nilai posttest kemampuan berpikir kritis siswa di analisis dengan uji t dan uji korelasi biserial. Sebelum melakukan uji t dan uji korelasi biserial, nilai posttets kemampuan berpikir kritis 
kelas eksperimen dan kelas kontrol diuji homogenitas dan normalitas. Hasil uji homogenitas nilai posttest diketahui bahwa kedua kelas mempunyai varians yang sama atau homogen Hasil uji homogenitas disajikan pada Tabel 2.

Uji homogenitas digunakan untuk mengetahui seragam atau tidaknya nilai posttest antara kelas eksperimen dan kelas kontrol. Uji homogenitas menggunakan uji Fisher. Hasil uji normalitas nilai posttest menunjukkan bahwa data berasal dari populasi yang berdistribusi normal Hasil uji homogenitas disajikan pada Tabel3. Uji $\mathrm{t}$ dilakukan untuk mengetahui apakah terdapat pengaruh pembelajaran biologi model PBL terhadap kemampuan berpikir kritis. Hasil uji t diperoleh thitung 6.778 dan ttabel 2,01. Data tersebut menunjukkan terdapat pengaruh signifikan antara pembelajaran IPA model PBL terhadap kemampuan berpikir kritis siswa kelas V di SDN Mekarsari 1 Kabupaten Tangerang sehingga dapat dinyatakan bahwa pembelajaran model PBL berpengaruh positif terhadap kemampuan berpikir kritis siswa pada pembelajaran IPA.

Tabel 1 Perbandingan Hasil Pretest - Posttest Kelas Eksperimen dan Kelas Kontrol

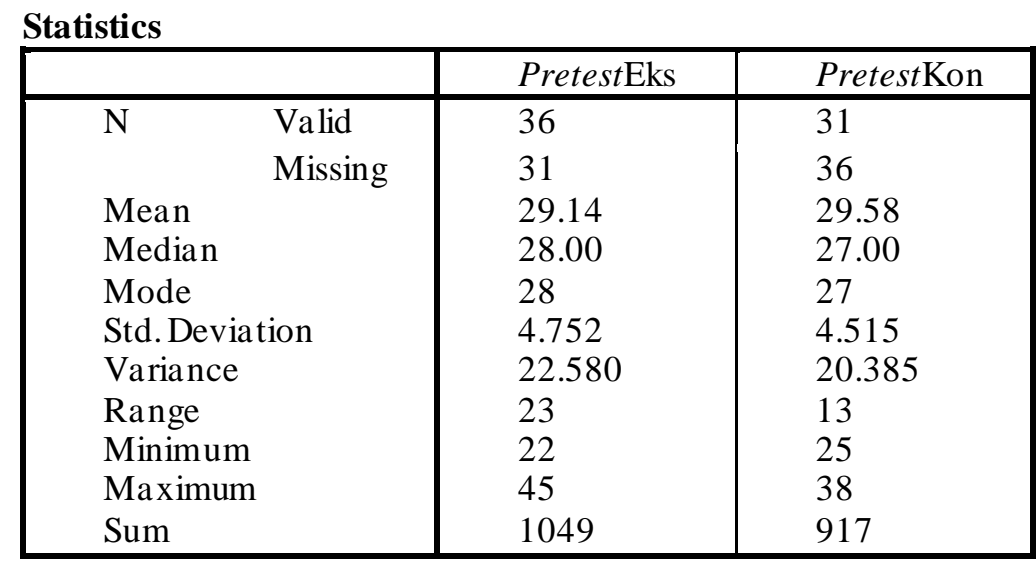

Berdasakan tabel 4.1 di atas nilai yang diperoleh dari kelas eksperimen yaitu nilai terendah 23, nilai tertinggi 45, rata-rata 29.14, median 28.00, modus 28, dan simpangan baku 4.752. Lalu nilai yang diperoleh dari kelas kontrol yaitu nilai terendah 25 , nilai tertinggi 38, rata-rata 29.58, median 27.00, modus 27, dan simpangan baku 4.515. Dapat dilihat bahwa hasil pretest ini menunjukkan kemampuan awal berpikir kritis. 


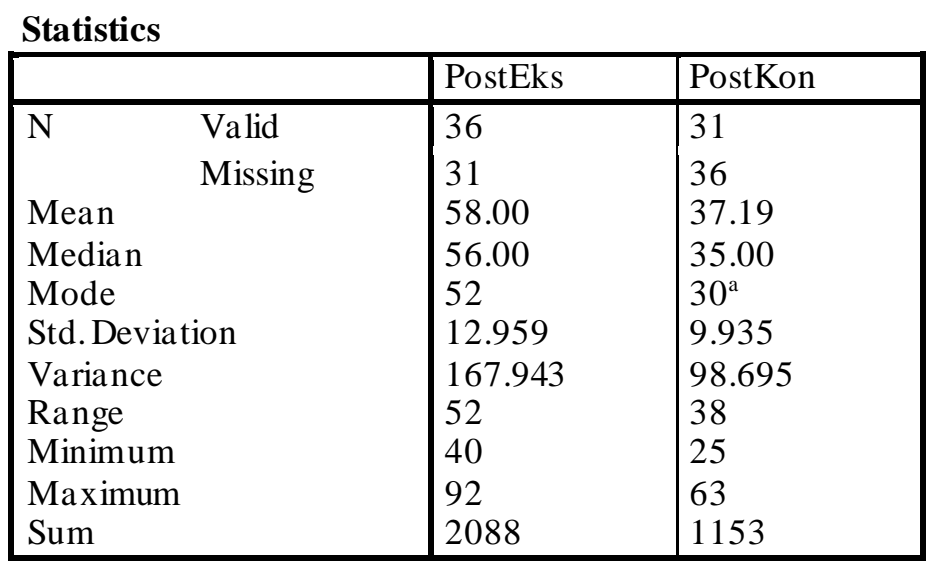

Berdasarkan tabel 4.2 di atas hasil posttest ini menunjukkan kemampuan berpikir kritis siswa pada kelas eksperimen dan kelas kontrol. Hasil nilai posttest yang diperoleh dari kelas eksperimen yang telah diajarkan menggunakan model pembelajaran ProjectBased Learning mendapatkan nilai terendah 40, nilai tertinggi 92, rata-rata 58.00, median 56.00, modus 52, dan simpangan baku 12.959. Lalu hasil nilai posttest yang diperoleh dari kelas kontrol yang telah diajarkan menggunakan model pembelajaran konvensional mendapatkan nilai terendah 25 , nilai tertinggi 63 , rata-rata 37.19 , median 35.00, modus 30, dan simpangan baku 9.935. Dapat dilihat bahwa hasil posttest pada kelas eksperimen mengalami kenaikan dari hasil pretest sebelumnya, dan pada kelas kontrol tidak mengalami kenaikan.

Tabel 2. Uji Homogenitas

Test of Homogeneity of Variances

Pretest

\begin{tabular}{|l|l|l|l|}
\hline Levene Statistic & df1 & df2 & Sig. \\
\hline .285 & 1 & 65 & .596 \\
\hline
\end{tabular}

Test of Homogeneity of Variances

Posttest

\begin{tabular}{|l|l|l|l|}
\hline Levene Statistic & df1 & df2 & Sig. \\
\hline 3.143 & 1 & 65 & .081 \\
\hline
\end{tabular}

Berdasarkan tabel 2 di atas diketahui nilai signifikan untuk data pretest kelas eksperimen dan kelas kontrol adalah 0.596 maka dapat disimpulkan bahwa data pretest untuk kelas eksperimen dan kelas kontrol berasal dari kelompok yang memiliki varian s yang homogen. Berdasarkan tabel di atas diketahui nilai sign. untuk data posttest kelas 
eksperimen dan kelas kontrol adalah 0.081 maka dapat disimpulkan bahwa data posttest untuk kelas eksperimen dan kelas kontrol berasal dari kelompok yang memiliki varian s yang homogen.

Tabel 2 Hasil Perhitungan Uji Normalitas Chi-Kuadrat Pretest

Test Statistics
\begin{tabular}{|l|l|l|}
\hline & Pretest $\mathrm{Eks}$ & Pretest $\mathrm{Kon}$ \\
\hline Chi-Square & $20.833^{\mathrm{a}}$ & $18.065^{\mathrm{b}}$ \\
Df & 10 & 8 \\
Asymp. Sig. & .022 & .021 \\
\hline Test Statistics & PostEks & PostKon \\
\hline & $11.000^{\mathrm{a}}$ & $12.194^{\mathrm{b}}$ \\
\hline Chi-Square & 17 & 12 \\
Df & .857 & .430 \\
Asymp. Sig. &
\end{tabular}

Berdasarkan tabel 3 dapat dilihat bahwa kelas eksperimen memiliki nilai sign $0.022>0.05$ dan kelas kontrol memiliki nilai sign $0.021>0.05$. Maka dapat disimpulkan data untuk kelas eksperimen dan kelas kontrol berdistribusi normal.

Berdasarkan tabel 4 dapat dilihat bahwa kelas eksperimen memiliki nilai sign $0.857>0.05$ dan kelas kontrol memiliki nilai sign $0.430>0.05$. Maka dapat disimpulkan data untuk kelas eksperimen dan kelas kontrol berdistribusi normal.

Selanjutnya, Pengujian hipotesis dilakukan dengan menggunakan uji-t sebagaimana yang tertera pada table 4 :

Tabel 4 Hasil Uji-t (Posttest)

Paired Samples Test

\begin{tabular}{|c|c|c|c|c|c|c|c|c|c|}
\hline & \multicolumn{5}{|c|}{ Paired Differences } & \multirow[b]{3}{*}{$\mathrm{t}$} & \multirow[b]{3}{*}{ df } & \multirow{3}{*}{$\begin{array}{l}\text { Sig. (2- } \\
\text { tailed) }\end{array}$} \\
\hline & & \multirow[b]{2}{*}{ Mean } & \multirow{2}{*}{$\begin{array}{l}\text { Std. } \\
\text { Deviation }\end{array}$} & \multirow{2}{*}{$\begin{array}{l}\text { Std. } \\
\text { Error } \\
\text { Mean }\end{array}$} & \multicolumn{2}{|c|}{$\begin{array}{l}95 \% \text { Confidence } \\
\text { Interval of the } \\
\text { Difference }\end{array}$} & & & \\
\hline & & & & & Lower & Upper & & & \\
\hline Pair 1 & $\begin{array}{l}\text { PostEks - } \\
\text { PostKon }\end{array}$ & 21.581 & 17.727 & 3.184 & 15.078 & 28.083 & 6.778 & 30 & .000 \\
\hline
\end{tabular}

Berdasarkan table 4 di atas dari hasil perhitungan dapat diperoleh data berupa nilai signifikan (2 tailed) 0.000. Menurut kriteria pengujian hipotesis bahwa $\mathrm{H}_{0}$ ditolak, maka dengan demikian dapat dikatakan bahwa "Terdapat perbedaan kemampuan berpikir kritis siswa pada kelas yang menggunakan model pembelajaran Projecet-Based Learning dengan kelas yang menggunakan model pembelajaran konvensional". 
Pada data pretest menunjukkan bahwa data berdistribusi normal dan memiliki varians yang homogen. Kemudian dilakukan uji kesamaan rerata dengan uji-t dan didapatkan hasil bahwa kemampuan awal siswa pada kelas eksperimen dan kelas kontrol adalah sama, maka tidak ada perbedaan kemampuan berpikir kritis siswa antara kelas eksperimen dan kelas kontrol. Setelah diberi perlakuan yang berbeda antara kelas eksperimen dan kelas kontrol maka diakhir pertemuan diadakan posttest. Berdasarkan analisis data posttest menunjukkan bahwa data berdistribusi normal dan memiliki varians yang homogen. Kemudian dilakukan uji kesamaan rerata dengan uji-t dan didapatkan hasil bahwa terdapat perbedaan kemampuan berpikir kritis antara siswa yang diberi model pembelajaran Project-Based Learning dengan siswa yang diberi model pembelajaran konvensional.

Berdasarkan hasil penelitian diatas dapat disimpulkan bahwa terdapat perbedaan hasil belajar dengan menggunakan model pembelajaran Project-Based Learning berpengaruh terhadap kemampuan berpikir kritis dan dapat meningkatkan berpikir kritis siswa kelas V pada mata pelajaran IPA di SDN Mekarsari I Kabupaten Tangerang.

Berdasarkan hasil analisis deskriptif presentase menunjukkan bahwa skor kemampuan berpikir kritis kelas eksperimen lebih tinggi pada aspek memberikan penjelasan sederhana, menyimpulkan, mengatur strategi dan taktik, dan memberikan alternatif pemecahan masalah. Hal tersebut dapat terjadi karena siswa dilatih untuk memecahkan permasalahan dan mempresentasikan hasil diskusi di depan kelas, siswa dituntut untuk berpartisipasi aktif dalam bertanya dan menanggapi pertanyaan sehingga siswa mampu mengembangkan kemampuan berpikir kritisnya khususnya pada aspek memberikan penjelasan sederhana.

Aspek memberikan penjelasan sederhana meliputi memfokuskan pertanyaan, menganalisis argumen, dan bertanya dan menjawab pertanyaan (Ennis 2011). Hal ini sejalan dengan Winarni (2006) dan Setiawan (2005) dalam Santoso (2010) yang menyatakan bahwa pembelajaran yang meminta siswa untuk memahami atau merumuskan masalah, tujuan, dan hipotesis, melakukan pengamatan atau penyelidikan, mencari data, serta menganalisis untuk menjawab permasalahan yang telah dirumuskan dapat mengembangkan kemampuan berpikir kritis siswa.

Aktivitas membaca teks permasalahan pada pembelajaran model PBL, melalui aktivitas tersebut siswa dilatih untuk mengembangkan kemampuan dalam 
mempertimbangkan sumber belajar apakah dapat dipercaya atau tidak. Kemampuan tersebut masuk dalam aspek membangun keterampilan dasar (Ennis 2011). Namun skor yang diperoleh kelas eksperimen hampir sama dengan skor yang diperoleh kelas kontrol yaitu cukup kritis. Hal ini dikarenakan berpikir merupakan suatu kemampuan yang harus dilatihkan dan tidak dapat diperoleh secara instan. Hal tersebut sejalan dengan pernyataan Redhana (2012) bahwa kemampuan berpikir kritis memerlukan pembelajaran dan latihan terus menerus.

\section{SIMPULAN DAN SARAN}

Berdasarkan hasil penelitian yang dilakukan di SD Negeri Mekarsari 1 Kabupaten Tangerang, maka diperoleh kesimpulan bahwa setelah dilakukan pengujian hipotesis berbantu aplikasi SPSS versi 22 dengan nilai thitung sebesar 6,778 pada taraf signifikan $\alpha=5 \%$ yang kemudian dibandingkan dengan ttabel sebesar 2,028 sehingga $\mathrm{H} 0$ ditolak dan H1 diterima. Dengan demikian dapat dikatakan bahwa terdapat perbedaan terhadap kemampuan berpikir kritis IPA antara kelas yang diberi model pe mbelajaran ProjecetBased Learning dengan kelas yang diberi model pembelajaran konvensional. Pada kelas eksperimen nilai rata-rata posttest lebih tinggi dibandingkan rata-rata nilai posttest pada kelas kontrol. Hal ini terjadi karena adanya perbedaan perlakuan selama proses pembelajaran. Sehingga dapat disimpulkan bahwa terdapat perbedaan terhadap kemampuan berpikir kritis IPA antara kelas yang diberi model pembelajaran Projecet Based Learning dengan kelas yang diberi model pembelajaran konvensional.

Model pembelajaran Project-Based Learning dapat dijadikan sebagai salah satu model pembelajaran yang digunakan dalam proses pembelajaran IPA yang menyenangkan di dalam kelas yang dapat meningkatkan berpikir kritis siswa.

\section{DAFTAR PUSTAKA}

Agus, S. (2013). Cooperative Learning Teori \& Aplikasi PAIKEM. Yogyakarta: Pustaka Pelajar.

Agus, S. (2016). Model-Model Pembelajaran Emansipatoris. Surabaya: Pustaka Pelajar.

Akhmadi, A. (2017). Pendekatan Saintifik Model Pembelajaran Masa Depan. Surabaya: Alpha. 
Aqib, Z., \& Murtadlo, A. (2016). Kumpulan Metode Pembelajaran Kreatif \& Inovatif. Bandung: PT. Sarana Tutorial Nurani Sejahtera.

Daryanto. (2014). Pendekatan Pembelajaran Saintifik Kurikulum 2013. Yogyakarta: Gava Media.

Desmita. (2011). Psikologi Perkembangan Peserta Didik. Bandung: PT. Remaja Rosdakarya.

Frijters, S., GT Dam., and G Rijlaarsdam.2008. Effectof DialogicLearningonValueLoaded Critical Thinking. ElsevierLearning and Instruction1 (18):66-82.

Gunawan, R. (2016). Pendidikan IPS Filosofi, Konsep, dan Aplikasi. Bandung: Alfabeta.

Hosnan, M. (2014). Pendekatan Saintifik dan Konstektual dalam Pe mbelajaran Abad 21. Jakarta: Ghalia Indonesia.

Isrok'atun, \& Rosmala, A. (2018). Model-Model Pembelajaran Matematika. Bandung: PT. Bumi Aksara.

Kusumaningrum, N. H. (2016). Peningkatan Kemampuan Cara Mengkritik pada Mata Pelajaran Bahasa Indonesia melalui Strategi Critical Incident pada Siswa Kelas Vi Mi Al-Hidayah Benowo Surabaya. Surabaya: Fakulas Tarbiyah dan Keguruan UIN Sunan Ampel . Diakses dari HYPERLINK "http://digilib.uinsby.ac.id/15842/" http://digilib.uinsby.ac.id/15842/

Lestari, K. E., \& Yudhanegara, M. R. (2017). Penelitian Pendidikan Matematika. Bandung: PT Refika Aditama.

Parwati, N. N., Suryawan , I. P., \& Apsari, R. A. (2017). Belajar dan Pembelajaran. Depok: PT. Raja Grafindo Persada.

Riadi, E. (2014). Metode Statistika Parametrik \& Nonparametrik. Tangerang: PT. Pustaka Mandiri.

RobbinsS.2005.ThePathtoCriticalThinking.On line at HYPERLINK "http://hbswk.hbs.edu/archive/4828.html" \h ttp://hbswk.hbs.edu/archive/4828.html Samatowa, U. (2018). Pembelajaran IPA di Sekolah Dasar. Jakarta: PT. Indeks.

Sugiyono. (2017). Metode Penelitian Kuantitatif, Kualitatif, dan R\&D. Bandung: Alfabeta CV.

Suharsimi, A. (2014). Prosedur Penelitian Suatu Pendekatan Praktik. Jakarta: Rineka Cipta.

Sumarmo, U., Hendriana, H., \& Rohaeti , E. E. (2017). Hard Skills dan Soft Skills Matematik Siswa. Jakarta: Aditama. 
Susanto, A. (2012). Teori Belajar \& Pembelajaran di Sekolah Dasar. Jakarta: Prenadamedia Group.

Sani, RA. 2014.Pembelajaran Saintifik untuk ImplementasiKurikulum 2013. Jakarta: Penerbit Bumi Aksara

Warsono, \& Hariyanto. (2017). Pembelajaran AktifTeori dan Asesmen. Bandung: PT. Remaja Rosdakarya.

Wisudawati, A. W., \& Sulistyowati, E. (2014). Metodologi Pembelajaran IPA. Jakarta: PT. Bumi Aksara. 